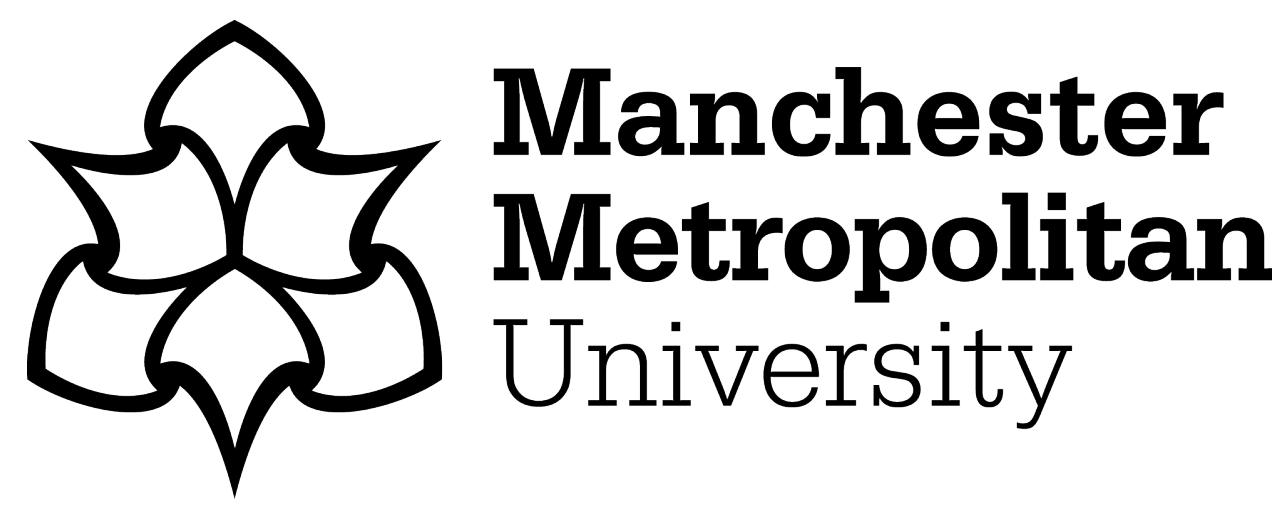

Fujioka, R and Stobart, J (2018) Global and local: retail transformation and the department store in Britain and Japan, 1900-1940. Business History Review, 92 (2). pp. 251-280. ISSN 2044-768X

Downloaded from: https://e-space.mmu.ac.uk/621440/

Version: Accepted Version

Publisher: Cambridge University Press (CUP)

DOI: https://doi.org/10.1017/S0007680518000417

Please cite the published version 
Global and local: retail transformation and the department store in Britain and Japan, c.1900-1940

Rika Fujioka, Kansai University, and Jon Stobart, Manchester Metropolitan University

Email address for correspondence: j.stobart@mmu.ac.uk

\section{Biographies}

Rika Fujioka is professor of macro-marketing at Kansai University in Japan. Her publications include a co-edited book Global Luxury: organizational change and emerging markets since the 1970s (2018), and "The development of department stores in Japan: 1900s-1930s", Japanese Research in Business History, (2014).

Jon Stobart is professor of history at Manchester Metropolitan University in the UK. His publications include Sugar and Spice: Grocers and the Grocery Trade in Provincial England, 1650-1830 (2013) and "Cathedrals of Consumption? Provincial Department Stores in England, c.1880-1930," Enterprise and Society, (2017). 


\title{
Global and local: retail transformation and the department store in Britain and
} Japan, c.1900-1940

\begin{abstract}
Department stores are often seen as transformative of both retail and wide social practices. This paper offers a comparative analysis of department stores in early twentieth-century Britain and Japan to assess the extent to which there were universal qualities defining the operation, practices and experience of department stores, and explore the ways in which they might be seen as transforming retailing in the two countries. Despite similarities in their origin, organisation and offer to customers, we highlight the greater diversity of British department stores and their incremental development. Japanese stores were a far more powerful force for change because they formed part of a concerted and conscious programme of modernisation.
\end{abstract}

\section{Introduction}

Department stores are seen as a defining feature of retail transformation in the late nineteenth and early twentieth centuries; their recent demise seems symptomatic of a further retail shift - out of town and into virtual space. ${ }^{1}$ Their origins might be contested, with the Paris Bon Marché, Stewart's Marble Palace in New York or - more contentiously perhaps - shops like Bainbridge's of Newcastle or Kendal Milne in Manchester all having a claim to be the first department store, but their spread and influence across the globe seems readily apparent. ${ }^{2}$ They appeared first in major cities across the USA and Europe, later spreading to Russia, Japan, South America, the Middle

\footnotetext{
${ }^{1}$ Vicki Howard, From Main Street to Mall: the Rise and Fall of the American Department Store (Philadelphia, 2015).

2 See, for example, Jan Whitaker, The Department Store: History, Design, Display (London, 2011).
} 
East and a range of British dominions. ${ }^{3}$ Their association with metropolitan centres underpins the view of department stores as important vehicles for urban, retail and social modernisation. In some places, including Japan, they were consciously deployed as instruments of westernisation, ${ }^{4}$ a role that has led some historians to see them as agents in an increasing homogenisation of the processes and practices of consumption. ${ }^{5}$ Yet they also spread to small towns in Europe and North America, where they 'brought modern retailing to outposts' and formed 'sources of pride for communities outside major retail centers' ${ }^{6}$ In both instances, modernity is linked to metropolitan values and practices, be that at a global or national scale, and modernization involved rolling these out to peripheral areas.

All this assumes that there was a set of qualities and attributes that defined department stores and set them apart from other forms of retailing, such as the multiple retailers or chain stores that grew rapidly in parts of Europe and North America in the later

\footnotetext{
${ }^{3}$ Henry Pasdermadjian, The Department Store: its Origins, Evolution and Economics (London, 1954), esp. 3-7; Whitaker, Department Store; Evan Roberts, "'Don't Sell Things, Sell Effects': Overseas Influences in New Zealand Department Stores, 1909-1956," Business History Review 77 (Summer 2003): 265-89; Marjorie L. Hilton, "Retailing the Revolution: The State Department Store (GUM) and Soviet Society in the 1920s," Journal of Social History 37 (Summer 2004): 939-64.

${ }^{4}$ See Toru Hatsuda, Hyakkaten no Tanjo [The Birth of the Department Store] (Tokyo, 1993); Yuki Jinno, Shumi no Tnajo: Hyakkaten ga tsukutta Teisuto [The Birth of Department Stores' Taste] (Tokyo, 1994); Taketoshi Yamamoto and Tamotsu Nishizawa (eds.), Hyakkaten no Bunkashi [Social History of Department Stores] (Tokyo, 1999).

${ }^{5}$ In his pioneering work, Pasdermadjian discusses department stores in largely generic terms, only occasionally referring to the specificities of place. He implies that stores everywhere were like those in North America and Britain.

${ }^{6}$ Howard, Main Street to Mall, 25.
} 
nineteenth century. In reality, defining the department store is notoriously difficult: the model changed over time and space, and nomenclature was far from universal. Whilst they were called department stores in the USA and Japan, British shops rarely used the term before the 1930s (although the term was used and understood in the trade press) and French stores were often 'grand magasins'. Apart from size (which is, of course, a relative rather than absolute measure), what characterised these stores was their organisation into separate departments, coupled with central operating functions, including accounts or marketing. ${ }^{7}$ Writing in the 1950s, Jefferys suggested that British department stores should be defined as any shop with at least four separate departments, including women's and children's wear - a threshold which included scores of shops outside more formal definitions. ${ }^{8}$ He also recognised their evolutionary nature by adding a category of 'part department stores' (those which did not quite meet the full criteria) and the importance of female consumption in shaping their status and character. More recently, Markus, has focused on the size and character of the retail space, designed to enhance display and encourage free movement. ${ }^{9}$ Governments and trade organisations drew on similar criteria. The Department Store Association in Japan, for instance, followed the 1937 Department Stores Law in defining them as having two or more departments that included clothing, food, homeware, and

\footnotetext{
7 Gareth Shaw, "The evolution and impact of large-scale retailing in Britain," in The Evolution of Retail Systems c. 1800-1914, eds. John Benson and Gareth Shaw (Leicester, 1992), 140; Howard, Main Street to Mall, 11.

8 James Jefferys, Retail Trading in Britain, 1850-1950 (Cambridge, 1954), 326.

9 Thomas Markus, Buildings and Power (London, 1993), 308.
} 
haberdashery, and with a sales area over $3,000 \mathrm{~m}^{2}$ in one of the six largest cities, or over $1,500 \mathrm{~m}^{2}$ in other cities. ${ }^{10}$

Such definitional difficulties are particularly challenging in the British context because of the highly varied nature and size of stores and the evolutionary nature of their development. However, Howard notes that censuses in the USA also undercounted department stores because they omitted many small-town stores not formally identified as department stores - just the kind of businesses picked up by Jefferys' criteria. ${ }^{11}$ Both within and between countries, then, there were large variations in what a department store might comprise: Macy's was not the same as Harrods, and both were different from provincial stores like Miller and Paine in Lincoln, Nebraska, and Brookfields in Stafford, England. Americans were horror struck by the floorwalkers in London stores, but metropolitan shoppers may have felt equally at odds with the cramped rooms in many provincial stores. ${ }^{12}$ These differences bring into focus fundamental questions about what it meant to be a department store, and about the relationship between local and national cultures, economies and societies on the one hand and the development and character of department stores on the other. More fundamentally, they challenge the universality of the department store's apparently common qualities and their role in retail change.

\footnotetext{
${ }^{10}$ Japan Department Stores Association (JDSA), Nihon Hyakkaten Kyokai 10 nenshi [A 10 Year History of the Japan Department Stores Association] (Tokyo, 1959), 14-5

${ }^{11}$ See Ian Mitchell, "The Victorian provincial department store: a category too many?," History of Retailing and Consumption, 1:2 (2015), 149-63; Howard, Main Street to Mall, 54.

${ }^{12}$ Erika Rappaport, Shopping for Pleasure. Women in the making of London's West End (Princeton, NJ, 2000), 153.
} 
In this paper, we explore the development of department stores in two contrasting contexts - early twentieth-century Britain and Japan. Our purpose is twofold. First, we wish to ascertain the extent to which there were universal qualities defining the operation, practices and experience of department stores. Is the department store a meaningful category when looking across the globe and down the urban hierarchy, and how do we best understand how local circumstances shaped the character of department stores? Second, and building from this, we want to assess their role as agents of retail and consumer transformation: did stores in Britain and Japan have a similarly transformative effect on the lives of consumers, and again how might we understand any differences in their impact?

Our comparators are deliberately chosen because they represent very different cases of department store development. In Japan, department stores were introduced as a conscious mechanism of modernisation and westernisation, and formed a genuinely new form of retailing; in Britain, most department stores grew organically and thus built on a long tradition of retailing that presaged many aspects of department store retailing. We take a pragmatic approach to defining the objects of our enquiry: stores counted in official enumerations plus any others that met Jefferys's threshold of four separate departments. This allows us to include both metropolitan leviathans and provincial Lilliputians (shops such as Brookfield's and the Empire Trading Stamp Company in Sheffield that lay outside formal definitions of department stores) and to explore the universality both of key aspects of department store trading and their impact on retailing and society more generally. We argue that department stores played a key role in retail, consumer and societal modernisation, but that the nature and process of modernity was contingent on local circumstances that were also critical in shaping the character and operation of retail business, even in a seemingly global 
phenomenon like department stores. We thus highlight the importance of comparative analysis in understanding the relationship between the global and local.

\section{The basics: growth, numbers and distribution}

The origins of British department stores were many and varied. A few were created $a b$ initio, most famously Selfridge's on Oxford Street, and others were opened as branches of a parent company, as seen with Lewis's during the 1880s. Most, however, grew organically, the classic model being that of the draper gradually expanding the range of goods on offer: adding ready made clothes and shoes, furniture, glass and china, perhaps jewellery and perfumes. Sometimes the retailer originally traded as a grocer (e.g Harrods or Broadbent's of Southport), outfitters (Fenwick's of Newcastle) or house furnishers (Sloper's of Devizes, Wiltshire); but the basic process of expansion remained the same. ${ }^{13}$ This was true even in Shaw's second 'revolutionary' stage of development: branches were often already trading in some form before they became department stores and many 'newcomers' were in reality older businesses. ${ }^{14}$

In Japan, the first wave of department stores also grew from drapery stores, but their character was completely different. Drapery and especially silk drapery stores were very difficult to establish in nineteenth-century Japan because only the Samurai class

\footnotetext{
${ }^{13}$ Jefferys, Retail Trading; Bill Lancaster, The Department Store: A Social History (Leicester, 1995), 10-12, 28-31; Morrison, English Shops and Shopping: An Architectural History (New Haven, CT, 2003), 140-3; J. Porter, “The Development of a Provincial Department Store, 1870-1939", Business History, 13 (1971): 281. Mitchell, "Victorian Provincial Department Store", is sceptical about links to earlier bazaars. ${ }^{14}$ Shaw, "Large-scale retailing", 140.
} 
were permitted to wear silk kimonos ${ }^{15}$. Since most Japanese department stores originated as stores that dealt in silk draperies, their early customers were only from the upper classes, making them very exclusive establishments. Staff needed significant knowledge and experience to be able to advise customers on the many conventions and rules governing silk kimonos. For example, fabrics patterned with flowers are often worn on celebratory occasions in Japan, but there are rules that govern the kind of flowers that should be worn in different seasons. Furthermore, silk drapers generally survived longer than other types of store at the time ${ }^{16}$ and those that transformed into department stores at an early stage had already been in business for two or three centuries: Matsuzakaya opened its first store in 1611, Shirokiya in 1662, and Mitsukoshi in 1673. These stores had already established a special and prominent place in Japanese society.

Given these differences in origin, it is no surprise that the number of stores was very different in the two countries. Jefferys estimates that there were 475-525 department stores in Britain by 1938, but Stobart has recently argued that the number was probably greater, identifying around 600 in England by the early 1930s, at least half of which were already trading as department stores around 1914. ${ }^{17}$ Many of these were small businesses, very different from their metropolitan counterparts, yet they all fulfilled Jefferys's essential criteria. Numbers in Japan were much smaller: in 1924 there were

\footnotetext{
${ }^{15}$ Shinzo Matsuda, Department Stores (in Japanese) (Tokyo, 1931), 77-82; Takashimaya, Takashimaya 135 nenshi [A 135 Year History of Takashimaya] (Osaka, 1968), 340-341.

${ }^{16}$ Kyoko Yamamuro, Ooedo Akinai Hakusho [Facts regarding stores in the Edo Period] (Tokyo, 2015), 60-

61.

17 Jefferys, Retail Trading, 59; Jon Stobart, “Cathedrals of Consumption? Provincial Department Stores in England, c.1880-1930," Enterprise and Society, 18:4 (2017), 810-45.
} 
twelve department stores run by only seven companies. By the time they first established an association in 1933, there were 25 department store companies and a further 12 companies that had not joined this association, although their sales floors were large enough and they sold a variety of merchandise (Table 1). This represented the tip of a much bigger retail iceberg: in 1933, there were 128,303 retailers in Tokyo alone. ${ }^{18}$

[Table 1 about here]

It might be argued that such profound differences in numbers reflect different definitions or different levels of maturity in the retail system. However, there is little to suggest that a more flexible definition, as taken for England, would significantly increase the figures for Japan. Moreover, the number of Japanese department stores remained fairly modest through the remainder of the twentieth century: in 1950 there were 111 stores, rising to 132 stores by $1960 .{ }^{19}$ A more convincing explanation links to the different origins of department stores and the different political-economic context in which they were established and grew. What we see in Japan is, in effect, a set of department stores that equates with the top end of a hierarchy of British stores that stretched from metropolitan leviathans to provincial Lilliputians. This impression is reinforced when we look at the geographical distribution of department stores in the two countries. In Japan most department stores developed initially in the largest cities such as Tokyo and Osaka, spreading by 1935 to other cities with populations of over 100,000, especially the capitals of prefectures (Table 2). Exceptions were rare:

\footnotetext{
18 JDSA, Nihon Hyakkaten Kyokai 10 nenshi, 4-10; Census of Commerce (1952, reprinted 1989).

${ }^{19}$ Japan Department Stores Association (JDSA), Heisei 25 nen Nihon Hyakkaten Kyokai Tokei Nenpo [ Annual report of Japan Department Stores Association in 2013] (Tokyo, 2013), 24-25.
} 
Darumaya in Fukui and Marusan-Tsuruya in Kushiro - relatively small towns that equated in size to English towns like Lincoln or Worcester.

[Tables 2 and 3 about here]

English department stores were spread across the country, in small towns as well as metropolitan areas. London dominated, Kelly's trade directories listing 88 by the 1930s, but each English county had at least one department store and sixteen had ten or more. ${ }^{20}$ These provincial patterns were often shaped by the presence of large towns and cities since those at the upper end of the urban hierarchy also contained the largest number of department stores (Table 3). However, the underlying socio-economic character of both these cities and their regions was highly varied and impacted upon department store growth in different ways. To take just three counties as examples: provision in County Durham in north-east England was centred on the industrial towns of South Shields, Stockton-on-Tees, West Hartlepool and especially Sunderland, each of which contained at least three department stores in the early 1930s. Provision in Warwickshire in the Midlands was dominated by industrial Birmingham, with seven department stores; but the former leisure resort of Leamington Spa also had three small department stores. In Sussex on the south coast, it was seaside resorts that stood out, most notably Brighton (seven stores), but also Eastbourne, Hastings and Worthing (two or three apiece). ${ }^{21}$ This last group of towns points to the importance of tourism in the development of department stores, which could form important attractions in their own right. The presence of holidaymakers with money to spend helps to explain the relatively high position in Table 3 of Brighton and Bournemouth; but a well-heeled

\footnotetext{
20 Stobart, “Cathedrals of Consumption”, Table 1.

21 Kelly's Directories, 1931, 1932, 1934.
} 
resident population was also important, for example in Leamington or in picturesque county towns like Chester or Norwich.

The result of this range of stimuli to development was that Britain had a much denser network of department stores, places as small as Cromer in Norfolk (4176) and Devizes in Wiltshire (6058) having shops that fulfilled Jefferys's basic criteria and were locally recognised as department stores. These were clearly very different from their counterparts in larger cities, let alone London stores like Harrods or Swan and Edgar or their equivalents in Tokyo and Osaka. ${ }^{22}$ This reflects both the different origins and development trajectory of British department stores and the broader market being served. Japanese stores were firmly aimed at the upper middle classes and elite, although this gradually expanded downwards as industrialisation produced a growing white-collar class. In Britain, there is a well-established binary of stores: those serving the middle and upper-middle classes, which competed on the basis service and quality, and those serving the working and lower-middle classes, which competed primarily on price. $^{23}$ To this, we need to add a third set: small department stores serving a mixed clientele drawn from a very localised area. This varied customer base lay behind the much wider distribution of stores, with many serving a relatively modest market area. Japanese stores, by contrast, needed to be able to draw on a large hinterland to generate sufficient demand from wealthy middle-class customers and so were located in big cities. The flagship stores of the five largest department stores were located in the commercial area of the largest cities.

\footnotetext{
22 Stobart, "Cathedrals of Consumption".

23 Peter Scott and James Walker, “The British "Failure” That Never Was? The "Productivity Gap" in LargeScale Interwar Retailing: Evidence from the Department Store Sector," Economic History Review 65
} (2012), 296. 
We should be wary, though, of being reductionist in our understanding of department stores distribution. A number of factors were important, including competition from other department stores, the attraction of transport links and the scale of business. Taking these in turn, there was considerable overlap in market areas served by different stores both in Britain and Japan. Brown's of Chester, as an upmarket store, was able to attract wealthy customers from the Wirral, which lay more naturally in the market area of Liverpool and its sizeable department stores, including Lewis's, Blackler's, Owen Owen, and Bunney's. A Mass Observation study of the shop in the 1940s noted one customer's recollection that these well-to-do customers would prefer 'a shopping day involving a run in the car through the Wirral to the ancient and always interesting city of Chester, rather than to the ferry crossing of the River Mersey'. ${ }^{24}$ Quite apart from highlighting shopping as leisure, this underscores the importance of transport to the success and sometimes to the location of department stores. By the 1930s, the motorcar was beginning to have an influence in Britain, at least for stores serving wealthier customers, but far more important were suburban trains and especially omnibuses and trams. ${ }^{25}$ These brought suburbanites to the city centre and were thus vital in ensuring that a sufficient number of customers could reach the store. It was no accident that Bainbridge's in Newcastle chose to advertise in its 1912 Souvenir Store Guide that 2500 trams passed their door every day. ${ }^{26}$ Similarly, though from the opposite perspective, a fictional shopkeeper in a secondary centre within Stoke-on-

\footnotetext{
24 Mass Observation (ed.) H.D. Whitlock, Browns and Chester. A Portrait of a Shop (London, 1947), 181. See also Lancaster, Department Store, 32-4.

25 Pasdermadjian, Department Store, 24, 43; Lancaster, Department Store, 12-13; Rappaport, Shopping for
} Pleasure, 122-6.

${ }^{26}$ Quoted in Lancaster, Department Store, 13. 
Trent, bemoaned that 'the electric trams ... simply carried to Hanbridge [the city centre] the cream and much of the milk of Bursley's trade'. ${ }^{27}$ It is notable that the trams ran past the doors of all four department stores in Stoke's city centre, although their location was driven initially by the location of the market and the main shopping thoroughfare. ${ }^{28}$ In London as well, department stores were conveniently placed in relation to underground stations, but it was the prestige of the street that generally determined their location.

The link between transport termini and department store growth was much more direct in Japan. Hankyu Railway started its rail service in 1910, connecting Osaka with suburban areas for the growing numbers of white-collar commuters. When the company refurbished its facilities at Umeda station in 1922, it also decided to launch a store for its customers within the building. Hankyu opened this store in 1925, mainly selling food and including several restaurants, but in 1929 it was redeveloped into the first Hankyu department store, with 10 floors covering about 10,000 $\mathrm{m}^{2}$ and selling an expanded range of merchandise including silk and cotton kimonos. Its founder, Ichizo Kobayashi, pointed out the benefits of this location, as its customers were already at the station and did not need to be drawn in with promotions and advertisements, as was necessary for other department stores. ${ }^{29}$ Also, as a railway company, it was able to use

\footnotetext{
${ }^{27}$ Arnold Bennett, Old Wives' Tale (1908; Everyman Edition: London, 1935), 503.

${ }^{28}$ Jon Stobart, “City Centre Retailing in Late Nineteenth- and Early Twentieth-Century Stoke-on-Trent: Structures and Processes," in A Nation of Shopkeepers: Five Centuries of British Retailing, eds. John Benson and Laura Ugolini (London, 2003), 166-70.

${ }^{29}$ Ichizo Kobayashi, "Watashino Kigyo Senjyutsu [My Management Strategy]," in Zaikaijin Shiso Zenshu 2: Keiei Tetsugaku/Keiei Rinen [Collected works of Business People, ver. 2: Management Vision and Philosophy], eds. Keiichiro Nakagawa and Tsunehiko Yui (Tokyo, 1970), 113.
} 
the highly effective strategy of offering transport services during off-peak hours, so that its department store became a popular destination for housewives to go shopping in the daytime. In this way, the Hankyu department store had 100,000 visitors on an average weekday, while Daimaru had 70,000 and Mitsukoshi and Takashimaya each had 30,000. Also, while most department stores were at their busiest at around 3pm, the Hankyu department store usually had its peak hours between $5 \mathrm{pm}$ and $7 \mathrm{pm}$ due to its commuter customers. ${ }^{30}$

This success encouraged similar developments by other department stores. When a subway line opened near Mitsukoshi in 1932, the company built an underground entrance to its store, directly connected by a hallway to the subway station. This hallway was the work of a French designer; it had a marble ceiling and walls, and shop windows displayed Mitsukoshi's newest products. Mitsukoshi also covered a large part of the cost of the whole station, which was officially named 'Mitsukoshi-mae' (in front of Mitsukoshi), to honour this contribution. ${ }^{31}$ In this way, and in contrast with Britain, railway and subway lines sometimes had a more direct impact on the location of department stores and the retail geography of the city.

\section{Scale of operation: plots and premises}

Japanese stores operated at a large scale both in terms of the size of their premises and their turnover. The combined sales of all stores in the Department Stores Association in 1938 amounted to 642.56 million yen, which then peaked at 886.47 million yen in 1941

\footnotetext{
${ }^{30}$ Masayuki Taniuchi, Senzen Osaka no Tetsudo to Depart [Railway and Department Store in Osaka before the Second World War] (Osaka, 2014), 88.

31 Mitsukoshi, Mitsukoshi 100 nen no Kiroku [A 100 Year History of Mitsukoshi] (Tokyo, 2005), 128.
} 
in parallel with the growing number of stores. The gross margin of Mitsukoshi in 1905 was 537,000 yen (approximately $£ 58,000^{32}$ ), which increased to 2.37 million yen in 1915, then to 10.54 million yen in 1925 and peaked at 26.1 million yen in 1941 $(£ 2,827,000)$. Matsuzakaya had sales of almost 20 million yen $(£ 2,166,000)$ in 1919 , which increased fourfold by 1929 and sixfold by 193933. Such growth was supported by a period of rapid expansion of middle-class white-collar workers , but equally important was the fact that department stores were the only large, modern retailers in Japan at this time. ${ }^{34}$ They took a substantial share of the market, for example, accounting for almost 25 percent of total retail sales and 55 percent of clothing sales in Tokyo. ${ }^{35}$ In comparison, British department stores, faced with competition from multiple retailers and co-operative stores, captured only 1-2 percent of retail sales in 1900, rising to 3.5-5 percent by 1930; even in clothing and shoes, these figures were just 5.5-7 percent and 12-14 percent respectively. ${ }^{36}$ Moreover, only a handful of British stores were operating at the level of Mitsukoshi and Matsuzakaya. Harrods was exceptional, with sales peaking

32 The exchange rate between Shilling and Yen in this paper use the monthly exchange rate in January 1919 provided by Institute for Monetary and Economic Studies, Bank of Japan, http://www.imes.boj.or.jp/hstat/data/ferdd/index.html (accessed 26th April and 20th July 2017).

33 By contrast, the Tokyo Wholesale Price Index decreased by 39\% between 1919 and 1929, and a further 25\% by 1939: Institute for Monetary and Economic Studies, Bank of Japan.

34 In 1919 Matsuzakaya's sales share was $0.13 \%$ of Japan's Gross National Product (GNP) and 0.5\% of its Personal Consumption Expenditures (PCE), while Harrods's sales comprised $0.03 \%$ of the UK's Gross Domestic Product (GDP). (http://www.ukpublicspending.co.uk/piechart 1919_UK total (accessed 20th July 2017).

35 Torao Natanishi, Hyakkatenho ni kansuru Kenkyu [Investigation on the Department Stores Law]. (Tokyo, 1938), 31-32.

36 Jefferys, Retail Trading, 61. Including the greater number of stores identified by Stobart would increase this figure, but not substantially. 
in 1919 at $£ 1,850,000$, though several other London stores were turning over $£ 1$ million at this time and D. H. Evans, for example, returned profits of $£ 169,200$. In the provinces, James Howell \& Co of Cardiff had profits of $£ 73,246$ on a turnover of $£ 913,942$ in 1920, while Binns in Sunderland had a turnover in excess of $£ 760,000$ in $1921 .{ }^{37}$ These were the leviathans. Many other stores, both in London's suburbs and in provincial towns, operated at a much smaller scale. For example, Broadbents of Southport in Lancashire (with a 1931 population of 76,621) experienced good growth in the period 1914-34, turnover increasing more than threefold, but this still meant a peak of less than $£ 150,000$. Similarly, Cockayne's of Sheffield showed a gross profit of $£ 16,189$ in 1914 healthy, but in a completely different league from D.H. Evans or Howells, let alone Mitsukoshi and Matsuzakaya. ${ }^{38}$

Similar diversity marked the size and character of retail premises in Britain. By 1920, Harrods' Knightsbridge store covered $18,200 \mathrm{~m}^{2}$ with nearly $81,000 \mathrm{~m}^{2}$ of floor space; the new store opened by D.H. Evans in 1937 comprised 34,500 $\mathrm{m}^{2}$ over eight floors, and Binns in Sunderland enjoyed 28,000 $\mathrm{m}^{2}$ of sales space split between premises on either side of Fawcett Street. In contrast, Sloper's in Devizes occupied a modest double-fronted shop as did Woodward's in Leamington Spa, while the thirteen separate departments of the Empire Trading Stamp Company in Sheffield were each contained in very modest rooms in its Howard Street presmises. In Japan, the largest store was Mitsukoshi. Its first Western-style building, built in 1910, had a sales area of 5,210 $\mathrm{m}^{2}$ over three floors, but this grew progressively to $13,210 \mathrm{~m}^{2}$ over six floors in 1914 and to $50,843 \mathrm{~m}^{2}$ after it refurbished its main store with luxurious marble halls in 1935. By this time, there were

\footnotetext{
37 Michael Moss and Alison Turton. A Legend in Retailing: House of Fraser (London, 1989), 326, 316, 332, 291, 101-05.

38 Porter, "Provincial Department Store”, 284-5; Shaw, “Large-scale Retailing”, 152.
} 
another nine stores with over $10,000 \mathrm{~m}^{2}$ of floor space and even the smallest had $2132 \mathrm{~m}^{2}$ (Table 1).

The premises occupied by British department stores were almost always built up slowly over time as the shop expanded its range of goods and sales area. Stobart has shown how, in a variety of towns, the mean frontage of department stores (that is, the number of plots they occupied on a street) grew two- or three-fold between 1892 and $1932 .{ }^{39} \mathrm{~A}$ couple of examples serve to illustrate the general trend (see Table 4). Robinson Brothers of Carlisle experienced a gradual expansion of their English Street premises both before being acquired by Binns in 1926. The growth of Alfred Adderly \& Co of Leicester was more complex as they had premises on two parallel streets. The Market Place frontage was gradually expanded while the shop on Gallowtree Gate was moved until it adjoined the back of the Market Place premises, giving a store opening onto two streets. Both of these examples follow the process that Shaw has outlined for Beatties in Wolverhampton. ${ }^{40} \mathrm{He}$ argued that this allowed for the construction of larger, integrated premises that would provide suitable retail space and an impressive showcase for the business. For such buildings, island sites were preferable as this allowed wholesale reconstruction, sometimes at a monumental scale.

[Table 4 about here]

\footnotetext{
39 Stobart, "Cathedrals of Consumption", Table 5.

40 Shaw, "Large-scale retailing", 143-5. See also Briggs, Friends of the People: The Centenary History of Lewis's (London, 1956).
} 
Monumentalism is an idea closely linked with the department store across the world. ${ }^{41}$ Harrods' enlargement of their Knightsbridge store was a deliberate counter to Selfridge's enormous edifice on Oxford Street - part of a broader 'arms race' in the scale and opulence of building. Neo-classical styles were prevalent, with impressive cupolas adding external magnificence as well as facilitating the lighting of interiors through dramatic atria. Sweeping staircases added to the theatricality of the interior and the later addition of lifts and then escalators added to the spectacle - as they did in provincial stores across the USA. ${ }^{42}$ Elaborate and impressive buildings were by no means restricted to metropolitan stores: John Walsh's premises on High Street, Sheffield were integral to the Corporation's attempt to improve the grandeur of the street; Lewis's Manchester store incorporated a central well rising through six storeys, Binns's Sunderland store was built along the latest American lines, and Plummer Rodis in Bournemouth was built in the latest art deco style. ${ }^{43}$ This monumentalism contributed to their attraction as places to visit, but there were many smaller department stores with fewer architectural pretensions. Frontages were often built to meld with rather than stand out from neighbouring properties, as with Brookfield's in Stafford, Woodward's in Leamington Spa or even Schofield's in Leeds: a large store, but one where the frontage in Headrow remained an assortment of different architectural styles and separate entrances. Inside, the store also remained disjointed - a complaint familiar from Whiteley's Bayswater store and repeated elsewhere, including Brown's of Chester.

\footnotetext{
${ }^{41}$ See Whitaker, Department Store; Robert Proctor, “Constructing the Retail Monument: the Parisian Department Store and its Property, 1855-1914", Urban History, 33 (2006): 393-410; Morrison, English Shops; Moss and Turton, Legend of Retailing, 36-8.

42 Howard, Main Street to Mall, 56-61.

43 Morrison, English Shops, 172; Moss and Turton, Legend of Retailing, 360-61, 290-91
} 
While monumentalism and integration were not always a features of even quite important British stores, Japanese department stores almost invariably formed city landmarks. Mitsukoshi's 1914 store, for example, was built in the Renaissance style and was reputedly the largest store east of the Suez Canal. It boasted the first escalators seen in Japan in addition to elevators, heating, and emergency sprinklers, all of which comprised the latest technology at the time. Other department stores soon followed suit, constructing their own new Western-style buildings, including Matsuzakaya (1910) and Takashimaya (1911). These stores had landmark facades and equipment that, together with the events they staged, made them tourist attractions. Many stores hosted exhibitions of paintings and music concerts, creating considerable interest at a time when there were very few museums or concert halls in Japan. Takashimaya in Osaka staged a particularly successful event, building a copy of the famous shrine at Nikko that drew tens of thousands of visitors to the store every day over a three-week period in 1927.44

Such events were very challenging to organise and were only possible for the most powerful retailers - that is, department stores. The buildings were also hugely expensive to construct. To fund them, department stores were reformed and modernized from family-owned businesses to limited companies; a change that created huge cash infusions through initial public offerings. New buildings and new management structures were thus part of the same process of modernization and westernization: Mitsukoshi converted its organization into a limited company in 1904 and built its new store in 1913, while Takashimaya became a limited company in 1919,

44 Takashimaya, Takashimaya 150 nenshi [A 150 Year History of Takashimaya] (Osaka, 1982), 103-4. 
building a new stores three years later. ${ }^{45}$ Turning the argument around, only those retailers that could modernize and westernize we able to transform their business into department stores: modernization and department store development were thus part of the same retail strategy. In Britain, the process of modernization was more contingent and contested: department stores had to comply with local government schemes for street improvement, ${ }^{46}$ struggled to assemble large plots for flagship stores, and often remained family-owned businesses, in which modernity - especially when equated with American practices, was sometimes explicitly rejected. This helps to explain why Japanese department stores comprised the top end of a hierarchy of retailers (whether measured in turnover or floor space), while those in Britain were located at various different levels of this hierarchy.

\section{Management structures}

In part because of their gradual and organic growth, the early development of many British department stores was dominated by founders and their families. We see this in the names accorded to stores and in many store histories which dedicate a lot of space to discussion of the founder as a hero-figure. ${ }^{47}$ It is clear that men such as David Lewis, Hugh Fraser and William Debenham - and later Gordon Selfridge and Charles Digby

\footnotetext{
${ }^{45}$ Rika Fujioka, "The Development of Department stores in Japan: 1900s-1930s", Japanese Research in Business History, 31 (2014): 16-17.

${ }^{46}$ Selfridge's original plans for his Oxford Street store were rejected by London County Council because they contravened building regulations - see Lancaster, Department Store, 72 .

${ }^{47}$ See, for example, Briggs, Friends of the People; Maurice Corina, Fine Silks and Oak Counters: Debenhams, 1778-1978 (London, 1978); Moss and Turton, Legend of Retailing; Lancaster, Department Store, 58-84.
} 
Harrod - were remarkable businessmen, able to tap into growing markets and innovate in their retail practices. Yet they were part of a much longer and broader tradition of entrepreneurial shopkeepers. What made the management of most nascent department stores different was not simply the brilliance of the central figure, but also the delegation of responsibility to individual departments and their managers. In many cases, this traditionally meant the buyer who was responsible both for acquiring and selling the stock in their particular department. ${ }^{48}$ This devolved system is seen very clearly in the departmental structure of Cockayne's of Sheffield. For each of 28 different departments, from decorating and painting through foreign fancy drapery goods to the restaurant, there was at least one manager plus a number of assistants, salesmen, workroom hands, and the like. ${ }^{49} \mathrm{~A}$ similar management structure initially characterised many of the leading Japanese department stores, which continued under the direction of their founding families after they switched from being silk drapers. Whilst employees were raised in a harmonious "company family" community - a type of paternalism that went well beyond anything seen in Britain - managers were again responsible for their own departments, initially organized by type of fabric but later incorporating Western clothing and interior goods.

The management systems in both Britain and Japan were at least partly transformed by a conscious adoption of more 'modern' practices from overseas, especially the USA. In Britain, much of the credit is given to Gordon Selfridge and the management innovations that he introduced in his Oxford Street store. ${ }^{50}$ Of particular significance was the use of functional management, which involved centralised operations under

\footnotetext{
48 Pasdermadjian, Department Store, 21; Lancaster, Department Store, 56, 73.

49 Shaw, "Large-scale retailing".

50 See Scott and Walker, "British Failure”, 281-2; Lancaster, Department Store, 58-84;
} 
professional managers including heads of accounting, merchandise and later advertising. Pasdermadjian placed emphasis on the importance of the retail inventory method, which allowed store managers to track gross profits and stock value, control slow moving stock, improve accounting procedures and the grouping of merchandise lines, amongst many other things. These innovations reined in the power and independence of the departmental buyers and brought greater coherence to the appearance and organisation of the department store. However, as Scott and Walker note, they had less impact on sales processes and thus the customer's experience of the store. ${ }^{51}$ Moreover, any impact was spatially and hierarchically uneven, with metropolitan stores and the emerging stores groups (such as Debenham's and Lewis's) being quickest to adopt new systems and procedures.

This divide between traditionalists and modernists might be somewhat overplayed, although Scott and Walker note how provincial department stores were less likely to invest in new technology and new management systems and were therefore less efficient than their London counterparts. ${ }^{52}$ Similar differences were seen in Japan. When profits in the Mitsukoshi business began to decline after the Meiji Restoration in 1868, Mitsui Bank, a powerful partner company within the Mitsui Group of which Mitsukoshi was also a member, sent a manager to work at the nascent department store in 1895. Yoshio Takahashi modelled its new retail format on US department stores, especially Wanamaker. However, Ohsuke Hibi, a subsequent manager sent from Mitsui

\footnotetext{
${ }^{51}$ Pasdermadjian, Department Store, 87-8; Scott and Walker, “British Failure”, 282.

${ }^{52}$ Scott and Walker, “British Failure”, 299-301. This dichotomy does not take into account the smaller, often family-owned stores found in many British market towns; these were perhaps least likely to adopt new practices.
} 
Bank, later changed its model to be more like Harrods, following his investigations in the UK. Models of western modernity were not always American.

Despite the success of this new mode of operating for Mitsukoshi, other large stores including Matsuzakaya and Takashimaya - delayed converting into department stores, partly because their businesses remained profitable in their traditional format and partly because of the conservatism of older directors. By the 1920s, though, they too were modernizing; they sent their managers to department stores in Europe and the USA to learn about modern retailing and introducing new technologies and advanced operations. ${ }^{53}$ This shift required new managers, capable of successfully organizing the transformation, and newly established department stores needed managers who were able to run these huge new stores. Other stores began to hire managers from Mitsukoshi, reflecting the company's leading reputation and its managers' unique knowledge and experience of modern retailing. Daimaru, for example, hired Junkichi Satomi in 1923, a manager who had visited the West during his time at Mitsukoshi; when he became the director of Daimaru between 1941 and 1950 he oversaw the modernization of its management, such as introducing employment contracts and creating modern employment regulations. Iwataya also hired a manager who had worked for Mitsukoshi to run a new department store that it was opening in 1935, and it sent employees to the Hankyu department store in Osaka for training. The founder of Hankyu was Ichizo Kobayashi, who had worked for Mitsui Bank between 1892 and 1907, and had a good relationship with Mitsukoshi. In short, Mitsukoshi was seen as a market leader, both in business and management, so other department stores were keen to hire its managers to operate their own stores.

53 Rika Fujioka, Hyakkaten no Seisei Katei [The Development of Department Stores] (Tokyo, 2006), 40-65. 
Again, distinctions between British and Japanese stores partly reflect different development trajectories and corporate structures. Small provincial stores in Britain could gain access to knowledge about new American practices through the trade press and the exemplars of innovative British stores, including Selfridge's. However, they generally lay outside the formal knowledge-sharing mechanisms of the trade associations and found it more difficult to fund trips that allowed their owners or managers to gain personal experience of these innovations. Moreover, unlike Japan, there was no central political agenda of modernization that drove them to innovate and the managers of some stores saw such changes as not simply unnecessary, but also undesirable: modern practices and terminology, closely associated with the USA, were anathema. For instance, the Managing Director of Browns of Chester noted in 1926 that, “While Browns' policy is progressive, the American store influence now so prevalent in this country has been resisted ... Browns of Chester must never in any circumstances be called a Store. It is a shop". ${ }^{4}$ In part, of course, this was a reaction against the idea that 'Stores' served a lower class of clientele, whereas Browns courted wealthier customers; but similar reticence marked attitudes in other stores, both in Britain and elsewhere. The Canadian store, Eaton's, initially rejected the idea of bridal salons as being a 'damnable American idea - too flamboyant'. ${ }^{55}$ Such reactions found their echo in the conservatism seen in directors at Matsuzakaya and Takashimaya, but the old guard in Japan was more quickly superseded by younger and more progressive managers. Throughout these changes in structures and procedures, top management remained a predominantly male domain in British department stores, with a strong streak of

\footnotetext{
54 Whitlock, Browns and Chester, 217.

${ }^{55}$ Quoted in Vicki Howard, Brides, Inc.: American Weddings and the Business of Tradition (Philadelphia, 2006), 98.
} 
paternalism persisting well into the twentieth century, even in some of the larger groups. That said, there was an acknowledged role for female buyers from the late nineteenth century onwards and 28 of the 47 senior managers at Fenwick's of Newcastle were women by 1932. Moreover, some larger stores sought to follow the example of Parisian department stores, which paid high wages to some of its female workers, making them 'Queens of the Proletariat'. ${ }^{56}$ Yet most women's experience of working in department stores was in poorly paid shop floor or backroom jobs, even if they far outnumbered their male counterparts. A 1931 census of staff employed by the John Lewis Partnership enumerated 1663 women and 650 men, but they were mostly in relatively poorly paid roles (see Table 5 ).

\section{[Table 5 about here]}

The widespread employment of female shop assistants is seen as a particularly AngloAmerican phenomenon, with numbers being much lower in many European countries. ${ }^{57}$ However, in Japan, whilst management remained predominantly male, the number of female shop workers was quite high by the 1930s. A contemporary study by Hoshino found that women comprised 47,55 , and 61 percent of the workforce in the three largest department stores in Osaka, many of them working in the store restaurants. However, few of them saw this work in terms of career progression; many simply enjoyed wearing the Western-style uniforms and commuting to the modern department stores for a few years, viewing it as a social experience prior to marriage. Their salaries were quite low, mostly less than 30 yen per month, and did not increase during their

\footnotetext{
56 Lancaster, Department Store, 122, 143-4, 176; T. McBride, “'A woman's world': department stores and the evolution of women's employment", French Historical Studies, X (1978), 681.

57 James Jeffery and Derek Knee, Retailing in Europe. Present Structure and Future Trends (London, 1962).
} 
career; by comparison, female bus conductors earned 40 yen per month and male workers at the department stores who graduated from professional schools had starting salaries of 35 yen per month, with a view to progressing as their careers developed. ${ }^{58}$ The stores themselves considered women to be inferior to men in the labour force, whilst female workers were also unenthusiastic about learning advanced skills. This created problems for some stores - especially those newly established in the 1920 s - as they struggled to retain female employees. In order to address this problem and secure the necessary personnel, Hankyu established a women's vocational school in 1936 and Daitetsu opened a women's commercial school in 1937. For the parent railway companies, this was also a strategy to increase the number of commuters between the suburbs, where the women lived, and the schools, which were located in the city centre..$^{59}$

\section{Customers experiences: service and self-service}

Department stores are often seen as having transformed the experience and practices of shoppers, ushering in a new era of modern consumerism and shopping through their innovative retail practices and spaces. ${ }^{60}$ In assessing the veracity of these claims, it is useful to examine how these processes infolded in and impacted on different social and cultural contexts. In terms of retail practice, we examine the customer service and the

\footnotetext{
${ }^{58}$ Shuichiro Hoshino, "Joteiin wo Chushin to seru Hyakkaten no Kenkyu [Study on Female Staff in Department Stores]," Keizai Jisho, 4(12), 1933: 22-32.

59 Taniuchi, Senzen Osaka, 326-354.

60 This tradition can be traced from Pasdermadjian, Department Store, through Daniel Miller, The Bon Marché Bourgeois Culture and the Department Store, 1869-1920 (Princeton, 1981), to Lancaster, Department Store.
} 
provision of facilities that created a 'modern' leisurely shopping environment; from the perspective of the customer, we explore changing shopping experiences, especially for women. 61

A high level of customer service was not new, but department stores often sought to exploit it as something that made them distinctive. Japanese department stores that had grown from silk drapers drew on their long tradition of customer service. Mitsukoshi, for example, distributed a handbook to its staff in around 1907 that showed what was expected of its sales staff. This included: (1) always paying attention to customers, so they should keep an eye on what was happening all around them; (2) always thinking about and anticipating what customers want, so they are on the same wavelength; (3) welcoming not only customers who are clearly intending to make a purchase, but also those who are just browsing and enjoying walking around the store; (4) welcoming all customers equally and courteously, not giving preferential treatment to wealthylooking customers; (5) never yawning, appearing sulky or gossiping; always maintaining good posture and a smile, and being polite and courteous with customers at all times. ${ }^{62}$

This high level of service differentiated department stores from other retailers and the effective management of sales staff meant it could be maintained, no matter what previous sales experience of each staff member; with clear guidelines and modern organizational management, high quality service was assured. Such guidelines, and the close regulation of staff that they implied, closely reflected practice in European

\footnotetext{
${ }^{61}$ See Howard, Main Street to Mall, 53-6; Rappaport, Shopping for Pleasure, 74-107; Lancaster, Department Store, 171-94; Rosalind Williams, Dream Worlds: Mass Consumption in Late Nineteenth Century France, (Berkeley, Ca., 1982).

62 Mitsukoshi, 100 Year History, 366-367.
} 
department stores. As early as 1887 the Draper's Record advocated Wannamaker's system of staff management, but a growing number of metropolitan stores introduced their own education departments whilst others looked to the Bon Marché in Paris, for example in recruiting only grammar school girls or poaching staff trained in other department stores. ${ }^{63}$ Such practices continued well into the 1930 s, at least in stores aiming at a middle- and upper-class clientele, in part because it helped to distinguish them from the growing number and variety of multiple retailers. We get a flavour of this from the interviews recorded by Mass Observation in their study of Browns of Chester. One working-class woman noted that "People say the assistants there are nicer than anywhere else. They're so helpful, you see"; another agreed: "the assistants there are really nice. They let you look round and tell you where everything is. They show you everything". ${ }^{64}$ Such high levels of customer service required sales assistants to engage in lengthy discussions with customers, ascertaining and fulfilling their requirements, and often offering advice - again, a practice with deep roots in earlier retail formats. ${ }^{65}$ Other British department stores took a different approach, aiming for greater efficiency rather than high levels of service. This was especially true of stores like Lewis's that served a working and lower middle-class clientele and sometimes involved allowing customers to help themselves to goods arranged on tables or placed in boxes - a practice which David Lewis adopted from the outset in his Manchester store, which opened in 1880.66

\footnotetext{
63 Lancaster, Department Store, 138-42; Miller, Bon Marché, 77-111.

64 Whitlock, Browns and Chester, 216, 217.

65 Bruno Blonde and Ilja Van Damme, "From Consumer Revolution to Mass Market", in J. Stobart and Vicki Howard (eds) Routledge Companion to Retail History (London, 2018).

66 Briggs, Friends of the People, 66.
} 
Browsing and the open display of goods are often seen as a key characteristic of department stores. Whilst these were established elements of shopping practice in eighteenth-century Britain, ${ }^{67}$ department stores developed and deployed techniques for displaying goods in ways that were more complex, elaborate and varied than was possible in smaller stores. Some goods were laid on tables, placed in boxes or draped over bannisters, and growing use was made of glass display cabinets. These were ubiquitous by the turn of the century and differed from those deployed in earlier shops by being placed on the shop floor or incorporated into counters. The former were joined from the late nineteenth century by mannequins modelling clothing and in the 1920 s by more complex tableaux which combined a set of associated goods or outfits - for example sporting equipment or spring fashions. In some ways, these echoed the increasingly sophisticated window displays mounted by London and some of the larger provincial stores, Co-operative Central Stores often proving particularly innovative in this regard. ${ }^{68}$ At the same time, however, many department stores, including Lewis's, adhered to older traditions of crammed window displays and massed goods within the shop.

Japanese stores imported new ideas of display from the West, often adopting a British rather than American model. There were glass cabinets containing expensive imported products, but these remained locked until a sales assistant came with a key. Equally, while stationery and books were displayed openly, sales assistants would move a step closer if customers showed interest in these products. Indeed, staff handbooks

\footnotetext{
${ }^{67}$ Clare Walsh, "The Newness of the Department Store: a View from the Eighteenth Century," in Cathedrals of Consumption: The European Department Store, 1850-1939, eds. Geoffrey Crossick and Serge Jaumain (Aldershot, 1999) 46-71.

${ }^{68}$ Stobart, "Cathedrals of Consumption".
} 
described that the best time to approach customers was when they picked up a product to inspect it more closely. ${ }^{69}$ This high level of customer service was expected and welcomed by Japanese customers and was quite different from the 'modern' self-service shopping that characterised many American stores. Sales assistants did much more than was claimed in the USA, where a store manager proclaimed that 'the goods sell themselves, and the clerks merely wrap them up and take the money'. ${ }^{70}$

Similar priorities and practices were apparent in Britain. The women interviewed by Mass Observation reported that the assistants in Browns were there to serve customers rather than them helping themselves. More generally, the sales assistant helping and advising customers from behind a counter remained common in many stores into the post-war period. Photographs of the glove department in Howell's of Cardiff in the late 1920s show numerous glazed cabinets and open displays, but two well-dressed women stand at counter inspecting goods in a way that closely resembles the illustration of Benjamin Coles' trade card, produced some 200 years earlier - the scale of the shop is different, but the practices remain largely unchanged. Similarly, a photograph of the menswear department at Harrods, taken in 1930, shows men browsing ties and other accessories which are on open display on the shop floor, but those engaged in buying are stood or sat at a glazed counter while being served by suited assistants. ${ }^{71}$

Department stores also offered their customers a wide range of additional services, which made their visit a pleasurable experience. British department stores built on the

\footnotetext{
${ }^{69}$ Mayumi Nagano, Anokoro no Depart [The Department Stores at that time] (Tokyo, 2012), 15. 70 Quoted in Whitaker, Department Store, 202. In reality, the 'through-floor' design only became widespread in the USA from the 1920s - see Howard, Main Street to Mall, 19, 56-62.

${ }^{71}$ Moss and Turton, Legend of Retailing, 334, 140; Nancy Cox, The Complete Tradesman. A Study of Retailing, 1550-1820 (Aldershot, 2000), 137.
} 
earlier tradition of bazaars which, with their dioramas and waxworks, frequently formed places of entertainment as well as retailing. The range of leisure activities grew to include orchestras and bands, fashion shows and demonstrations of hat making, celebrity visits and novelty acts, balloon launches and pageants. ${ }^{72}$ These were aimed at making the department store a place to visit as well as shop: the expense was repaid in greater footfall and greater sales. Linked to this was a set of rather more mundane facilities which were aimed at making the customer more comfortable and allowing them to stay in the store longer: tearooms, restaurants and rest rooms. Rappaport argues that the last of these were particularly significant for women at a time when public conveniences were mainly for men. ${ }^{73}$ The importance of such facilities is apparent from their presence in even quite modest provincial department stores (e.g. Brookfields in Stafford) and in those with an essentially working-class or lower-middle class clientele, like Lewis's. Indeed, this challenges Scott and Walker's suggestion that it was only stores serving wealthier customers that sought to compete on service. ${ }^{74}$

To an extent, such entertainments and facilities were culturally specific, but their presence in Japanese department stores links closely to the agenda of westernisation. Following a visit made to London in 1906, the CEO of Mitsukoshi, Ohsuke Hibi, decided to model his main store on Harrods. In addition to creating a comfortable shopping environment for its customers, he introduced various services to attract family customers to the store: weekly piano and subsequently violin concerts in the customer lounge $(1906,1907)$, an art gallery (1907), and concerts by a Western-style band in the main hall (1909). This not only functioned as a showcase of Western musical

\footnotetext{
72 See Lancaster, Department Store, 94-107; Morrison, English Shops, 93-9.

73 Rappaport, Shopping for Pleasure, 74-107.

74 Scott and Walker, "British Failure", 296.
} 
instruments to stimulate sales, but was also an opportunity for Japanese consumers to become more aware of Western culture. While American department stores played classical music to reinforce their sophisticated image and to promote high-end sales, Japanese department stores used Western musical instruments in order to introduce and promote Western culture. ${ }^{75}$ Their new target customers were highly educated businessmen and their families, who had growing incomes during the interwar period of industrialization in Japan. Encouraged by the promotion of Western culture as advanced and exclusive, these customers had their own houses built to include a modern Western-style room and they bought fashionable Western products for their homes from department stores. The ideal image of modern life for many newly wealthy Japanese men at the time was to have a wife or daughter who played the piano or violin in their home: an amalgamation of Western taste and Japanese lifestyle. Elsewhere in Mitsukoshi stores there were exhibitions on Western lifestyle, including photographs of foreign countries, children's toys and the latest fashions. ${ }^{76}$ This linked to Osuke Hibi's philosophy also made good business sense in that it increased awareness and ultimately sales of key western goods.

This consciously educational role for entertainments and facilities made Japanese department stores different from their counterparts in the West as did the lack of continuities in retail format and leisurely shopping environments. This meant that Japanese department stores were more genuinely new retail and leisure spaces that offered customers profoundly different shopping experiences from those they were used to. This was liberating in some ways, but also problematic because customers

\footnotetext{
75 Yuko Tamagawa, “Music and Commerce Hand in Hand: Mitsukoshi and Music (in Japanese)," Toho Gakuen Daigaku Kenkyu Kiyo, 23 (1997): 27-59.

${ }^{76}$ Mitsukoshi, 100 Year History, 66-73.
} 
lacked a pre-existing culture of shopping that might provide appropriate points of reference. For instance, the Mitsukoshi store included an elegantly decorated customer lounge with Western-style tables and chairs, where shop assistants served tea and biscuits. These were popular with the store's upper-class customers and they attracted a lot of publicity, but most customers, especially women, did not realise they were allowed to go into the room and so just had a quick look from the door. ${ }^{77}$ Mitsukoshi had to circulate information leaflets on the facilities that were available to all the store's customers, making it clear that everyone was welcome to come into the store, even if they had no intention of buying anything - a key element of department stores on both sides of the Atlantic. ${ }^{78}$

Japanese department stores outside the biggest cities also caused culture shock when first opened, but were quickly assimilated into established social norms and created new consumer and social practices. In 1916, the provincial drapery store Yamagataya, in Kagoshima (Table 1), transformed into a department store, modelled on Mitsukoshi in Tokyo. Its new store had a huge impact on consumers who were initially surprised by the huge building because until then only temples had been constructed on this scale and local people did not have chance to visit Tokyo and Osaka due to lack of public transport at the time. The entrance was made from Italian marble and fronted by six Western-style window displays with large glass panes. People admired this store passionately, especially with its modern Western-style equipment including Austin's latest elevator, which became particularly popular among children on school trips. It

\footnotetext{
77 Mitsukoshi, 100 Year History, 39.

${ }^{78}$ Howard, Main Street to Mall, 18-19; Lancaster, Department Store, 30-31.
} 
also became common for college students to visit in order to buy cheap pencils and admire the beautiful young saleswomen in their fashionable uniforms. ${ }^{79}$

As this shows, Japanese stores were the haunt of young men and children - a contrast with the image of the department store being especially oriented towards women. Indeed, historians are often overly eager to identify the department store as a female space - a tradition that can be traced back to Zola and which links into wider notions of women's absence from the public sphere. ${ }^{80}$ This ignores the long history of female engagement with shopping and perhaps tells us more about male anxieties about women empowered through their consumption and their labour in department stores and other shops or turned into kleptomaniacs by the riches on offer. ${ }^{81}$ Shoplifting, reckless spending on their husbands' accounts and sexual impropriety were present, but were overblown in the popular imagination. Yet department stores did provide middle class women with respectable and practical spaces in which to spend time and money. Indeed, they were one of only a handful of publically-accessible buildings providing women's toilets - themselves an attraction and a means of keeping women in store for longer ${ }^{82}$ Moreover, department stores geared much of their advertising to women and images of store interiors frequently show them packed with female shoppers. In part as a response to this, some British department stores felt it necessary ${ }^{79}$ Yamagataya, A 247 Year History of Yamagataya (Kagoshima, 1998), 37-43. ${ }^{80}$ See, for example, Rachel Bowlby, Just Looking: Consumer Culture in Dreiser, Gissing and Zola, (London, 1985); Rappaport, Shopping for Pleasure; Mica Nava, "Modernity's disavowal. Women, the City and the Department Store," in Mica Nava and Alan O'Shea (eds), Modern Times. Reflections on a Century of English Modernity (London, 1996): 38-76.

${ }^{81}$ Blonde and Van Damme, "From Consumer Revolution to Mass Market"; Lancaster, Department Store, $175-82$.

82 Rappaport, Shopping for Pleasure, 74-107. 
to reassure male customers that they could access the departments that they wanted without the embarrassment of encountering along the way other less manly things, like the perfume department. Some had a separate entrance to their 'Man's shop', while many others contained smoking rooms, barbers or reading rooms where men might wait while their wives shopped. ${ }^{83}$

Japanese department stores were initially a male domain - a gendering of space shaped by traditional retail practices and by the nature of the Westernization process. ${ }^{84}$ The main customers of traditional drapers were men: they earned and handled the money while women took care of the home. Moreover, most of the Western products initially sold by department stores were for men: stationery, hats, umbrellas, walking sticks, clothing and shoes. It was only in the 1910s, when the male market was well established, that department stores target women and children, enticing them in with the modern facilities and entertainments described above. As in the West a generation or two earlier, Japanese department stores then became a place for middle-class women to visit, similar to going to see a play at the theatre. ${ }^{85}$

Once department stores succeeded in attracting women to the stores, their merchandise expanded to include products specifically for them, a practice which became increasingly profitable as occasions. At the same time, department stores also targeted specific Japanese customs, such as the wedding tradition for a bride's parents to buy

\footnotetext{
83 Lancaster, Department Store, 182-3; Moss and Turton, Legend of Retailing, 138, 140.

84 Yuki Jinno, Hyakkaten de Shumi wo Kau [Consumers Bought the Taste of Department Stores] (Tokyo, 2015), 54-56.

85 Mitsukoshi, 100 Year History, 86; Takashi Hirano, “Igirisu ni okeru Hyakkaten no Kigen to Shoki Hatten Patān: Nihon tono Hikaku [The Origins of England Department Stores and their Development by Comparison with Japanese stores]," Mita Shogaku Kenkyu 48(2) (June 2005): 76-77.
} 
goods for the couple's new home and life together, including many different kinds of kimonos for various occasions, a futon, and other furniture and homeware. This was a suitable occasion for women to visit a store for shopping and stores such as Mitsukoshi set up sales displays specifically to meet this demand. In these a wide range of goods ordinarily found in many different stores was brought together in one place, from traditional items to modern (i.e. western) imported objects and furnishings for their new life. In 1916 it introduced a concierge desk where customers could discuss details about the wedding party and their outfits, and in 1922 it launched a sales space exclusively for wedding-related products. From 1909 Takashimaya held annual exhibitions of the wedding furnishings bought by customers for their marriage ceremonies and new homes. The store further encouraged sales by using leaflets to advertise these products and its personalised service, and to assure consumers that its stores could cater for all their wedding requirements. Women's magazines also ran articles covering celebrities' wedding experiences, with beautiful pictures taken at department stores; it then became hugely attractive to young brides-to-be to buy the same fashionable products at the same stores. ${ }^{86}$ This was a highly effective marketing strategy for department stores and meant that women eventually became their best customers.

\section{Conclusions}

Comparative studies reveal both the general properties, principles and practices of department store retailing, and the particularities of time and place. Our study of

86 Rika Fujioka, "Taishoki no Konrei Jyuyo to Hyakkaten no Hatten [The Development of Department Stores with Bride’s Outfit: 1912-1926]," Kokuritsu Rekishi Minzoku Hakubutsukan Kenkyu Kiyo, 197, 2016, 127-143. 
Japanese and British department stores shows that they had much in common: both typically grew out of drapery stores and expanded by offering new lines of merchandise; they became 'cathedrals of consumption', with modern equipment and facilities (including elevators, glass display cases, tearooms and art displays), and they increasingly opened their doors to everyone, although the experiences of shoppers undoubtedly varied with age, class and gender. Many offered high levels of customer service, especially in comparison with American department stores, which were quicker to introduce self-service shopping, and the burgeoning network of chain stores found in Britain, where price and efficiency were often the key trading advantages. British and Japanese stores focused on expanding and perfecting the sales floors of their anchor stores with high-quality merchandise, prioritising this over the standardisation and chain store operation seen in America. At the same time, both took lessons on modern management structures from their counterparts in the USA. ${ }^{87}$

For all these similarities, Japanese and British department stores displayed important differences in their character and development trajectory. Department stores emerged much later in Japan, but then grew very quickly to enjoy a much larger share of total sales. In part, this growth and dominance reflects a lack of competition in the form of chain stores and Co-operatives, as well as independent retailers, which in Britain often offered a similar set of goods and sometimes a similar shopping experience. Indeed, it is possible to argue that certain British chain stores, including Boots and Marks \& Spencer, were effectively department stores by the 1930s; others, such as Woolworths were driving modern practices such as self-service.

87 See Howard, Main Street to Mall, 62-73. 
Yet the dominant position of Japanese stores was also a product of the size and complexity of the businesses which lay behind them: their scale of operation was much larger than most British stores, with a handful of department stores dominating the retail market in Japan. Well into the twentieth century, Britain was characterised by a large number of small independent department stores spread across the country in a dense network. Almost any town of note had at least one shop that could reasonably portray itself as a department store, able to meet most needs of the local consumer. In contrast, Japanese department stores were essentially metropolitan and thus corresponded with the upper tier of the British department store hierarchy comprising London stores such as Harrods, Selfridge's and D.H.Evans, and provincial stores like Kendals (Manchester), Bainbridges (Newcastle) and Muff Brown \& Co. (Bradford). Like their Japanese counterparts, these metropolitan stores primarily sold to upper and middle-class customers, whereas small town stores served a much wider cross section of society whilst others, like Lewis's, specifically targeted a working-class market. There was therefore much greater diversity in department stores in Britain than in Japan. Department stores could be many different things in a more mature and variegated retail system. But this heterogeneity does not undermine the department store as a meaningful category: their common and unique qualities help historians to identify and explore those aspects of organisation and practice that were central in producing retail and consumer transformation. Here, the distinctions between British and Japanese stores become more evident. Those in Japan effectively revolutionised and modernised retailing in a way that their British counterparts did not. The evolutionary development of many British stores, and their adoption and improvement of earlier forms of shop design and marketing, meant their impact was incremental. British shoppers had long been able to browse goods in a leisurely manner and in settings that facilitated leisurely 
shopping. In this sense, modernity came gradually and incrementally, despite the oftquoted impact of visionaries such as Gordon Selfridge. Japanese stores choosing to switch from traditional modes of selling to department store retailing were consciously choosing a very different modus operandum, one with profound implications for their shops, selling practices, customer base and identity. The wider impact of the decisions by individual firms was hugely important, in part because of their size, but also due to their continued emphasis on upper and middle-class consumers - those with political, economic and cultural influence. Perhaps most significant was their alignment with the government agenda of modernisation and Westernisation. Combined, this allowed Japanese department stores to lead the Westernisation of the Japanese lifestyle through the sales of their Western products and promotion of Western material culture and values.

Only through comparative analysis can these differences be brought into focus and laid alongside the long-term fortunes and impacts of department stores in different countries. What our analysis shows is that both the nature and process of retail modernization and the power of department stores to transform retailing and shopping, and to shape broader cultural and social practices, were contingent on local circumstances. The department store was a truly global phenomenon, but it was also a product of its local and national context. Provincial stores were not simply smaller copies of metropolitan giants, nor were Japanese stores slavish replicas of western models, despite the visits made to stores in other countries to learn about management practices and store layout. This reflected the economic, political and cultural setting in which the department store operated and also the longer history of retail and shopping practices in that place. 
Table 1. The location and the floor spaces of Department Store Association stores in 1933 in Japan

\begin{tabular}{|c|c|c|}
\hline Name of firm & $\begin{array}{l}\text { Location of main } \\
\text { store }\end{array}$ & $\mathrm{m}^{2}$ \\
\hline Mitsukoshi & Tokyo & 50,843 \\
\hline Hankyu Hyakkaten & Osaka & 42,664 \\
\hline Takashimaya & Osaka & 33,352 \\
\hline Shirokiya & Tokyo & 33,352 \\
\hline Daimaru & Osaka & 27,230 \\
\hline Matsuzakaya & Nagoya & 23,028 \\
\hline Matsuya & Tokyo & 22,889 \\
\hline Yamagataya & Kagoshima & 12,780 \\
\hline Tamaya Gofukuten & Fukuoka & 10,909 \\
\hline Tenmaya & Okayama & 10,149 \\
\hline Matsuya Hyakkaten & Fukuoka & 7,934 \\
\hline Hoteiya & Tokyo & 7,613 \\
\hline Marubutsu Hyakkaten & Kyoto & 7,560 \\
\hline Nozawaya & Yokohama & 7,412 \\
\hline Imai & Sapporo & 6,853 \\
\hline Darumaya & Fukui & 5,491 \\
\hline Tamaya & Sasebo & 5,431 \\
\hline Sentoku Hyakkaten & Kumamoto & 4,380 \\
\hline Sogo & Osaka & 4,175 \\
\hline Miyaichi-Daimaru & Kanazawa & 3,821 \\
\hline Jyuuichiya & Nagoya & 3,755 \\
\hline Fukuya & Hiroshima & 3,755 \\
\hline Fujisaki & Sendai & 3,557 \\
\hline Sanyo Hyakkaten & Shimonoseki & 2,281 \\
\hline Marusan-Tsuruya & Kushiro & 2,132 \\
\hline
\end{tabular}

Source: JDSA, A10 Year History, 8-9. 
Table 2. Japanese cities with Department Store Association stores by urban rank

\begin{tabular}{lrrrr}
\hline City & $\begin{array}{r}\text { Number of } \\
\text { department } \\
\text { stores in } \\
1933\end{array}$ & $\begin{array}{r}\text { Total floor } \\
\text { space }\left(\mathrm{m}^{2}\right)\end{array}$ & Population & $\begin{array}{r}\text { Urban rank } \\
\text { in } 1935\end{array}$ \\
\hline Tokyo & & & & \\
Osaka & 4 & 114,697 & $5,875,667$ & 1 \\
Nagoya & 4 & 107,421 & $2,989,874$ & 2 \\
Kyoto & 2 & 26,783 & $1,082,816$ & 3 \\
Yokohama & 1 & 7,560 & $1,080,593$ & 4 \\
Hiroshima & 1 & 7,412 & 704,290 & 6 \\
Fukuoka & 1 & 3,755 & 310,118 & 7 \\
Sendai & 2 & 18,843 & 291,158 & 8 \\
Sapporo & 1 & 3,557 & 219,547 & 10 \\
Kumamoto & 1 & 6,853 & 196,541 & 15 \\
Kagoshima & 1 & 4,380 & 187,382 & 16 \\
Sasebo & 1 & 12,780 & 181,736 & 18 \\
Okayama & 1 & 5,431 & 173,283 & 20 \\
Kanazawa & 1 & 10,149 & 166,144 & 21 \\
Shimonoseki & 1 & 3,821 & 163,733 & 22 \\
Fukui & 1 & 2,281 & 132,338 & 29 \\
Kushiro & 1 & 7,934 & 73,273 & 51 \\
\hline Sources & 2,132 & 56,170 & 77 \\
\hline
\end{tabular}

Sources: JDSA, A 10 Year History, 8-9; "Population Census".

Note: there were almost 300 cities in Japan at the time. 
Table 3. Town size, urban rank, and distribution of department stores in England, c. 1932: top twenty-five towns

\begin{tabular}{|c|c|c|c|}
\hline Town & $\begin{array}{c}\text { Number of } \\
\text { department } \\
\text { stores }\end{array}$ & $\begin{array}{c}\text { Urban } \\
\text { rank }\end{array}$ & $\begin{array}{r}\text { Population } \\
\text { (1931) }\end{array}$ \\
\hline London & 88 & 1 & 8110356 \\
\hline Birmingham & 10 & 2 & 1002603 \\
\hline Liverpool & 10 & 3 & 846101 \\
\hline Sheffield & 9 & 5 & 511757 \\
\hline Newcastle & 9 & 10 & 286255 \\
\hline Manchester & 8 & 4 & 766311 \\
\hline Sunderland & 8 & 18 & 185903 \\
\hline Leeds & 7 & 6 & 482809 \\
\hline Bristol & 7 & 7 & 397012 \\
\hline Brighton \& Hove & 7 & 17 & 202420 \\
\hline Norwich & 7 & 31 & 126207 \\
\hline Hull & 6 & 8 & 313649 \\
\hline Bradford & 6 & 9 & 298041 \\
\hline Plymouth & 6 & 16 & 208182 \\
\hline Middlesbrough & 6 & 23 & 138960 \\
\hline Bournemouth & 6 & 32 & 113557 \\
\hline Reading & 6 & 40 & 95369 \\
\hline Nottingham & 5 & 11 & 268801 \\
\hline Portsmouth & 5 & 12 & 252421 \\
\hline Leicester & 5 & 14 & 239111 \\
\hline Southampton & 5 & 19 & 176007 \\
\hline
\end{tabular}

Sources: Kelly's Directories; 1931 census 
Table 4. Growth of premises of Robinson Brothers of Carlisle and Adderly \& Co. of Leicester, c.1892-1932

\begin{tabular}{llll}
\hline & 1892 & 1912 & 1932 \\
\hline Robinson Brothers & $\begin{array}{l}\text { 38a-40 \& 54 English } \\
\text { Street }\end{array}$ & 30-40 English Street & 22-40 English Street \\
& 59 Market Place \& 37a & 57-61 Market Place \& & 47-55 Market Place \& \\
Adderly \& Co. & 39 Gallowtree Gate & 45-47 Gallowtree Gate \\
\hline
\end{tabular}

Sources: Kelly's Directories

Table 5. Staff numbers and wages in the John Lewis Partnership, 1931

\begin{tabular}{lcccc}
\hline & \multicolumn{2}{c}{ Men and boys } & \multicolumn{2}{c}{ Women and girls } \\
Weekly wage & Number & Percentage & Number & Percentage \\
\hline$>£ 10$ & 41 & 6.3 & 19 & 1.1 \\
$£ 6-£ 10$ & 92 & 14.1 & 63 & 3.8 \\
$£ 4-£ 514 \mathrm{~s}$ & 214 & 32.9 & 148 & 8.9 \\
$£ 2-£ 3$ 18s & 194 & 29.8 & 919 & 55.3 \\
$<£ 2$ & 109 & 16.8 & 514 & 30.9 \\
& 650 & & 1663 & \\
\hline
\end{tabular}

Source: Draper's Record, 6 February 1932 